\title{
PENINGKATAN KOMPETENSI PEDAGOGIK GURU SD NEGERI KARSAMENAK KOTA TASIKMALAYA MELALUI PENGGUNAAN MEDIA ICT (INFORMATION AND COMMUNICATION TECHNOLOGY
}

\author{
Nenden \\ SD Negeri Karsamenak, Jl. Perintis Kemerdekaan No.319, Kawalu, Tasikmalaya, Indonesia \\ Email: nenden46791@gmail.com
}

\begin{abstract}
Elementary school is the starting point for children to study. Various kinds of subjects are taught in the elementary schools, such as, Religion, Civics Education, Social Sciences (IPS), Natural Sciences (IPA), Mathematics, English, Regional Languages and other local content such as Information and Communication Technology. In computer learning, the introduction of ICT is needed in elementary schools. At the primaryschool level, the introduction of ICT is more likely focused on the ability to use computers and the internet rather than other media. This School Action Research (PTS) was conducted at SD Negeri Karsamenak, Tasikmalaya City. This research was conducted from 15 September 2018 to 15 November 2018. The subjects in this study were 9 teachers of SD Negeri Karsamenak Kota Tasikmalaya. Data collection techniques in this study were obtained through observations and field data notes, interviews, test results and notes on the results of reflections / discussions conducted by researchers and research partners. Based on the research results, it is found that pedagogic competence can be ranked through the use of ICT media. This is evidenced by the implementation of action research carried out for 3 cycles, where in the 3 cycles, the teacher's ability to master learning media and learning activities continues to increase. The aspects of understanding ICT, teacher cooperative attitudes during activities, applications and active participation in learning activities at the pedagogical competence of teachers shows an increase in results.
\end{abstract}

Keywords: Teacher Pedagogic Competence, ICT.

\begin{abstract}
ABSTRAK
Sekolah Dasar merupakan titik awal seorang anak menuntut ilmu. Berbagai macam mata pelajaran diajarkan di sekolah dasar seperti PAI, Pendidikan Kewarganegaraan, Ilmu Pengetahuan Sosial (IPS), IImu Pengetahuan Alam (IPA), Matematika, Bahasa Inggris, Bahasa Daerah dan muatan lokal lainnya seperti Teknologi Informasi dan Komunikasi. Pengenalan ICT sangat dibutuhkan dalam pembelajaran komputer di sekolah dasar. Pada tingkat sekolah dasar biasanya pengenalan ICT lebih cenderung ke arah kemampuan menggunakan komputer dan internet daripada media yang lain. Penelitian Tindakan Sekolah (PTS) ini dilakukan di SD Negeri Karsamenak Kota Tasikmalaya. Penelitian ini dilakukan dari tanggal 15 September 2018 sampai dengan 15 Nopember 2018. Adapun subjek dalam penelitian ini adalah 9 orang guru SD Negeri Karsamenak Kota Tasikmalaya. Teknik pengumpulan data diperoleh melalui observasi dan catatan data lapangan, wawancara, hasil tes dan catatan hasil refleksi/diskusi yang dilakukan oleh peneliti dan mitra peneliti. Berdasarkan hasil penelitian diketahui bahwa Kompetensi pedagogik dapat ditingkatkan melalui penggunaan media ICT. Hal tersebut dibuktikan dengan pelaksanaan penelitian tindakan yang dilakukan selama 3 siklus, dimana pada ke 3 siklus tersebut kemampuan guru dalam penguasaan media pembelajaran dan kegiatan pembelajaran terus meningkat. Aspek pemahaman terhadap ICT, sikap kooperatif guru selama kegiatan, aplikasi dan partisipasi aktif dalam kegiatan pembelajaran pada kompetensi pedagogik guru menunjukkan hasil peningkatan.
\end{abstract}

Kata Kunci: Kompetensi Pedagogik Guru, ICT.

Cara sitasi: Nenden. (2020). Peningkatan Kompetensi Pedagogik Guru SD Negeri Karsamenak Kota Tasikmalaya melalui Penggunaan Media ICT (Information and Communication Technology). J-KIP (Jurnal Keguruan dan IImu Pendidikan), 1 (2), 63-70. 


\section{PENDAHULUAN}

Sekolah Dasar adalah sekolah yang merupakan titik awal seorang anak untuk menuntut ilmu. Berbagai macam mata pelajaran diajarkan di sekolah dasar yaitu Agama, Pendidikan Kewarganegaraan, IImu Pengetahuan Sosial (IPS), IImu Pengetahuan Alam (IPA), Matematika, Bahasa Inggris, Bahasa Daerah dan muatan lokal yang lain seperti Teknologi Informasi dan Komunikasi.

Pengenalan ICT sangat dibutuhkan dalam pembelajaran komputer di sekolah dasar. Pada tingkat sekolah dasar biasanya pengenalan ICT lebih cenderung ke arah kemampuan menggunakan komputer dan internet daripada media yang lain (Lunandi, 1993). Hal ini dikarenakan pengenalan media komputer lebih dibutuhkan oleh siswa dalam proses pembelajaran dan pencarian informasi. Proses pengenalan ICT di tingkat sekolah dasar masih tergolong ringan dibandingkan dengan tingkatan pendidikan di atasnya. Pengenalan tentang komputer contohnya ialah pengenalan microsoft word, macam-macam perangkat keras, macam-macam perangkat lunak, cara untuk menghidupkan komputer, dan lain sebagainya.

Pemanfaatan ICT ini secara umum bertujuan menghubungkan murid-murid dengan jaringan pengetahuan dan informasi (Marno \& Idris, 2008). Selain itu mengembangkan sikap dan kemampuan murid-murid untuk belajar sepanjang hidup (life-long education), meningkatkan kinerja guru dalam bidang ICT. Menggunakan teknologi dalam proses pembelajaran mempunyai kelebihan, yakni mempermudah dan mempercepat kerja siswa, juga menyenangkan karena siswa berinteraksi dengan warna-warna, gambar suara, video, dan sesuatu yang instan.

Agenda besar pendidikan di Indonesia adalah bagaimana peningkatan mutu pendidikan bisa meningkat, sejajar dengan negara lain di Asia dan Dunia. Pendidikan yang bermutu hanya dapat dilahirkan oleh para pendidikan yang juga bermutu, yakni memiliki kualifikasi standar, profesional dan berdedikasi tinggi, sehingga pada gilirannya akan menghasilkan SDM yang handal. Guru memilki peran strategis dalam pembangunan pendidikan, karena guru sebagai ujung tombak pendidikan, implementator kurikulum dan pelaku pendidikan yang secara langsung bersentuhan dengan siswa. Muatan-muatan ideal dalam kurikulum menjadi tanggung jawab guru untuk merealisasikannya dalam kegiatan pembelajaran.

Dengan demikian, untuk keberhasilan pendidikan diperlukan guru-guru yang berkualitas. Peningkatan kualifikasi guru merupakan salah satu prioritas pemerintah Indonesia, hal tersebut sebagai wujud realisasi UU Guru dan Dosen No. 14/2005 yang mempersyaratkan guru untuk memiliki kualifikasi minimal S-1 dan memiliki sertifikat sebagai pengajar. Di samping kualitas akademik guru, kondisi peningkatan kualifikasi akademik guru, kondisi kekurangan guru juga masih dialami sebagian besar wilayah Indonesia pada berbagai jenjang pendidikan. Dengan demikian, jumlah guru saat ini, maupun pada masa-masa mendatang perlu ditingkatkan. Hal ini menjadi luar biasa mengingat kemampuan LPTK yang ada di Indonesia pada saat ini yaitu sejumlah 278 LPTK (termasuk 32 LPTK Negeri) belum mampu memenuhi jumlah guru yang dibutuhkan dalam waktu segera. Dalam hal ini penerapan sistem pendidikan jarak jauh mejadi pilihan yang tidak dapat dirawar-tawar lagi.

Saat ini model pendidikan guru sudah banyak dikembangkan diberbagai belahan dunia baik di Eropa, Amerika, Afrika maupun Asia. Pola-pola pendidikan guru yang dikembangkan setidaknya dapat dijadikan rujukan sebagai perbandingan untuk mengembangkan pola pendidikan guru khususnya di Indonesia. Dengan mengkaji pola pendidikan guru yang dilakukan oleh negara lain, dapat dikaji tentang efektivitas dan efisiensi model yang dikembangkan serta permasalahan yang dihadapi dan relevansinya untuk diterapkan di Indonesia. Secara spesifik dapat dikaji tentang model pembelajaran terbuka yang digunakan, rumusan kurikulum, format pendidikan guru perangkat teknologi yang digunakan, pengelolaan pendidikan guru. Pengkajian model pendidikan guru ini telah dibahas UNESCO dengan menerbitkan laporannya pada tahun 2002. Kerangka model pendidikan guru berbasis ICT yang dikeluarkan UNESCO menunjukkan adanya variabilitas dalam pengembangan guru dan salah satunya dengan pemanfaatan ICT. 
Sistem pembelajaran bagi guru yang telah memiliki status pegawai sipil (PNS) perlu didesain secara khusus berdasarkan atas kebutuhan dan kondisi yang ada. Dalam jumlah yang besar dan dalam waktu yang singkat semua guru Sekolah Dasar yang belum S-1 harus menempuh pendidikan S-1, jika menggunakan sistem konvensional saat ini dengan waktu yang lama dan tatap muka yang lebih banyak, dipastikan guru tersebut tidak dapat menjalankan tugasnya sebagai guru yang harus mengajar optimal di kelasnya. Maka perlu dirancang sebuah sistem pembelajaran yang mengakomodasi kebutuhan belajar tersebut, artinya guru tetap dapat mengajar dengan optimal dan kewajiban untuk meningkatkan kualifikasi menjadi S-1 melalui perkuliahan dapat terus berlangsung.

Sistem pembelajaran harus memenuhi aspek kemandirian belajar, sesuai karakteristik pendidikan untuk orang dewasa (andragogik), keterlibatan alat, media dan sumber belajar yang mempermudah kemandirian belajar (independent learning), namun keterlibatan mahasiswa dengan dosen harus tetap terjalin untuk melengkapi sistem pembelajaran mandiri dan mengatasi permasalahan- permasalahan yang dihadapi oleh mahasiswa selama belajar mandiri yang tidak terpecahkan dan perlu konsultasi langsung.

Merujuk pada analisis tersebut, khusus untuk peningkatan kualifikasi guru, diperlukan sebuah model pembelajaran yang didesain secara khusus dengan sistem pembelajaran jarak jauh dengan pemanfaatan IT yang bersifat interaktif dan berbasis dunia maya (virtual). Dengan demikian, peneliti tertarik untuk mengembangkan sebuah model pembelajaran dengan nama Model Pusat Sumber Belajar yang bersifat Virtual berbasis ICT (Education Centre Of Teacher Interactive Virtual) yang disingkat "EDUCATIVE" Berbasis E-Learning untuk Meningkatkan Kompetensi guru yang berdomisili di Kota Cimahi dengan sampel Mahasiswa PJJ PGSD pada Mata Kuliah Media Pembelajaran dan Pengembangan Bahan Pembelajaran SD.

Secara teoritik pembelajaran elektronik (online instruction, e-learning, atau web-based learning) memiliki tiga fungsi utama. Siahaan (2001) menjelaskan pembelajaran elektronik ini berfungsi sebagai suplemen yang sifatnya pilihan/optional, pelengkap (complement), atau pengganti (substitution) pada kegiatan pembelajaran di dalam kelas (classroom instruction). Dilihat dari karakteristik diatas, maka peneliti akan mengembangkan model EDUCATIVE dengan kategori pengganti (substitution). Dalam hal ini, e-learning yang harus dikembangkan bukan hanya sekedar memasukkan bahan ajar, namun lebih bersifat komprehensif, e-learning yang mampu mengakomodasi sistem pembelajaran yang mengatur peran guru, siswa, pemanfaatan sumber belajar, pengelolaan pembelajaran, sistem evaluasi dan monitoring pembelajaran (Sanjaya, 2007). Dalam hal ini e-learning yang diperlukan adalah learning management system (LMS) yang bersifat multimedia dan interaktif.

Hasil studi pendahuluan diketahui bahwa penggunaan media ICT pada SD Negeri 2 Karsamenak masih belum merata. Begitu juga dengan SD Negeri Karsamenak Kota Tasikmalaya, tidak semua guru mampu menggunakanMedia ICT. Oleh karena itu sebagai kepala sekolah bermaksud melakukan upaya peningkatan kompetensi pedagogik guru SD Negeri Karsamenak Kota Tasikmalaya melalui penggunaan media ICT. Oleh sebab itu masalah utama dalam penelitian tindakan sekolah (PTS) ini adalah peningkatan kompetensi guru melalui penggunaan media ICT pada semua guru SD Negeri Karsamenak Kota Tasikmalaya.

Adapun perumusan masalahnya adalah sebagai berikut: 1) Bagaimanakah peningkatan kompetensi pedagogik guru SD Negeri Karsamenak Kota Tasikmalaya setelah dilakukan pembinaan melalui penggunaan media ICT? 2) Bagaimanakah pelaksanaan penggunaan media ICT untuk meningkatkan kompetensi Guru SD Negeri Karsamenak Kota Tasikmalaya?

\section{METODE PENELITIAN}

Subjek dalam penelitian ini adalah guru SD Negeri Karsamenak Kota Tasikmalaya dengan jumlah sebanyak 9 orang. Penelitian ini dilakukan terhitung sejak tanggal 15 September 2018 sampai dengan 15 Nopember 2018. Dalam PTS ini, tindakan yang dilakukan adalah pelatihan dalam bentuk 
workshop yang diikuti seluruh guru dan kegiatan bimbingan dalam praktek langsung di kelas (khusus dilaksanakan untuk 2 orang guru yang menjadi subyek penelitian). Teknik pengumpulan data dalam penelitian ini diperoleh melalui observasi dan catatan data lapangan, wawancara, hasil tes dan catatan hasil refleksi/diskusi yang dilakukan oleh peneliti dan mitra peneliti.

\section{HASIL DAN PEMBAHASAN}

Penelitian ini dilakukan dengan tiga siklus yakni siklus 1, siklus 2 dan siklus 3. Deskripsi dari masing-masing siklus disajikan sebagai berikut:

\section{Siklus 1}

Pada siklus 1 kompetensi guru terhadap pemahaman ICT masih kurang. Hal ini diketahui dari hasil obeservasi awal terhadap guru yang menjadi pengajar di SD Negeri Karsamenak Kota Tasikmalaya, hanya beberapa orang saja yang mengenal lebih luas tentang ICT dan telah menggunakannya dalam dalam proses pembelajaran yang dilakukan.

Upaya yang dilakukan adalah membuat perbaikan perencanaan serta melakukan pendalaman materi didasarkan pada kebutuhan peserta, artinya hanya materi yang belum dipahami oleh sebagian besar peserta saja yang dibahas dalam kegiatan pelatihan. Pembuatan silabus berbasis ICT, RPP, penilaian, surat, dan lain-lain, menggunakan software untuk presentasi seperti: powerpoint dan menggunakan ICT: record-keeping, analisis, dan pelaporan. Penanyangan Powerpoint. Fokus pengamatan proses belajar mengajar (guru model) diarahkan kepada peserta didik, dan Demontrasi mengajar dilaksanakan dengan model class visit disekolah tempat guru model mengajar.

Hasil observasi dapat diperhitungkan bahwa untuk siklus 1 kompetensi guru yang mampu menguasai ICT tampak sebagaimana pada Tabel 1.

Tabel 1. Hasil Observasi terhadap Penguasaan Guru Siklus 1

\begin{tabular}{clc}
\hline No. & \multicolumn{1}{c}{ Kompetensi } & Persentasi penguasaan \\
\hline 1 & Pemahaman terhadap ICT & 33,33 \\
2 & Kompetensi Kooperatif Guru menggunakan ICT & 40,00 \\
3 & Aplikasi & 46,67 \\
4 & Kompetensi Partisipatif dalam Kegiatan Pembelajaran & 60,00 \\
\hline
\end{tabular}

Berdasarkan Tabel 1, maka dapat disimpulkan bahwa masing-masing guru yang mengikuti pembinaan melalui pengenalan ICT sebagai salah satu media pembelajaran memiliki kemampuan yang masih kurang. Lebih jelasnya tampak pada gambar 1.

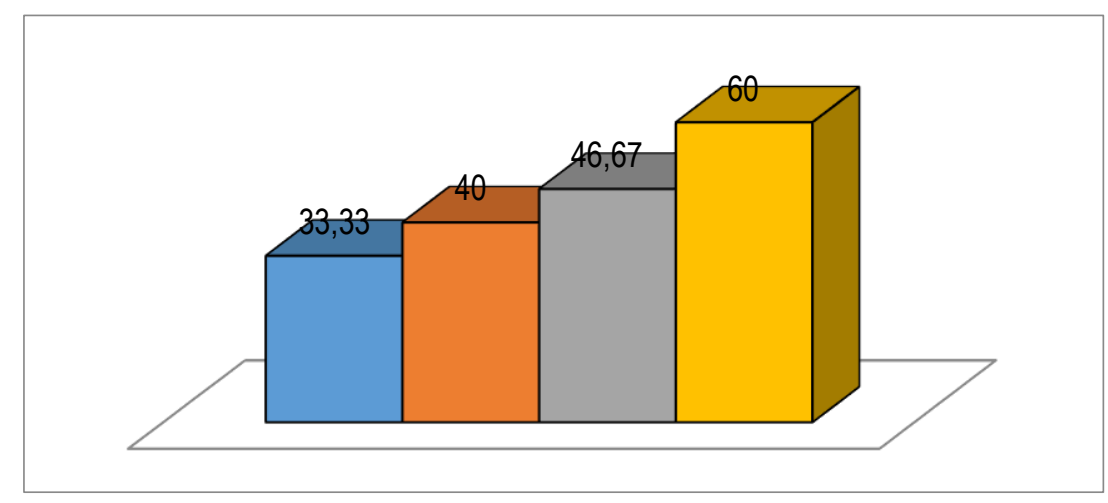

\section{Gambar 1. Grafik Hasil Observasi terhadap Penguasaan Guru Siklus 1}

Keterangan:

Biru : Pemahaman terhadap ICT

Merah : Kompetensi Kooperatif Guru menggunakan ICT

Hijau : Aplikasi 
Ungu : Kompetensi Partisipatif dalam Kegiatan Pembelajaran

\section{Siklus 2}

Hasil penayangan siklus 1 diketahui reaksi peserta terhadap sistim pembagian kelompok dengan kemampuan campuran berdampak positif terhadap peningkatan kompetensi guru. Kelebihan dari penerapan ICT adalah para peserta akan lebih banyak belajar dari rekannya sendiri. Pemilihan materi nampaknya tidak berpengaruh terhadap peserta karena karak teristik peserta relatif heterogen latar belakang pendidikannya. Tingkat pemahaman terhadap perangkat pembelajaran meningkat, hal ini diduga karena pengaruh penggunaan ICT terhadap kompetensi siswa.

Hasil observasi dapat diperhitungkan bahwa untuk siklus 2 kompetensi guru yang mampu menguasai ICT tampak meningkat, hal ini tampak sebagaiman pada Tabel 2.

Tabel 2. Hasil Observasi terhadap Penguasaan Guru Siklus 2

\begin{tabular}{clc}
\hline No. & \multicolumn{1}{c}{ Kompetensi } & Persentasi Penguasaan \\
\hline 1 & Pemahaman terhadap ICT & 80,00 \\
2 & Kompetensi Kooperatif Guru menggunakan ICT & 80,00 \\
3 & Aplikasi & 80,00 \\
4 & Kompetensi Partisipatif dalam Kegiatan Pembelajaran & 80,00 \\
\hline
\end{tabular}

Berdasarkan Tabel 2, maka dapat disimpulkan bahwa masing-masing guru yang mengikuti pembinaan melalui pengenalan ICT sebagai salah satu media pembelajaran memiliki peningkatan kemampuan pada siklus 2 namun masih perlu perbaikan. Lebih jelasnya tampak pada Gambar 2.

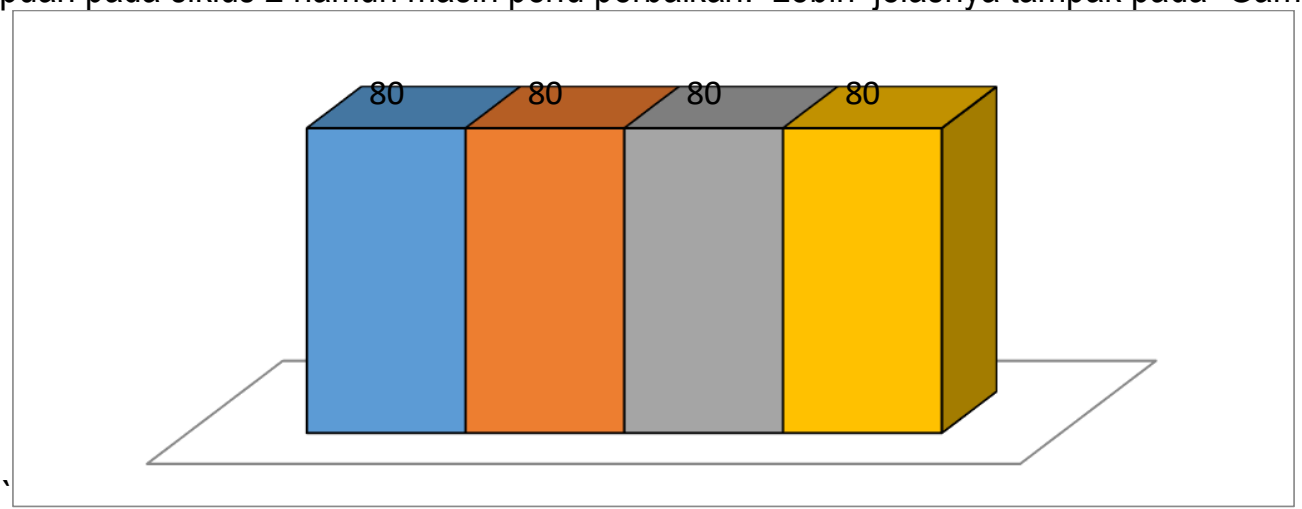

Gambar 2. Kemampuan Guru dalam Penguasaan ICT Siklus 2

Keterangan:

Biru : Pemahaman terhadap ICT

Merah : Kompetensi Kooperatif Guru menggunakan ICT

Hijau : Aplikasi

Ungu : Kompetensi Partisipatif dalam Kegiatan Pembelajaran

\section{Siklus 3}

Hasil penayangan siklus 3 diketahui peserta memiliki kemampuan dalam penguasaan ICT. Hasil observasi dapat diperhitungkan bahwa untuk siklus 3 kompetensi guru yang mampu menguasai ICT tampak meningkat, hal ini tampak sebagaimana pada Tabel 3. 
Tabel 3. Hasil Observasi terhadap Penguasaan Guru Siklus 3

\begin{tabular}{clc}
\hline No. & \multicolumn{1}{c}{ Kompetensi } & Persentasi penguasaan \\
\hline 1 & Pemahaman terhadap ICT & 93,33 \\
2 & Kompetensi Kooperatif Guru menggunakan ICT & 100,00 \\
3 & Aplikasi & 80,00 \\
4 & Kompetensi Partisipatif Dalam Kegiatan Pembelajaran & 100,00
\end{tabular}

Berdasarkan Tabel 3, maka dapat disimpulkan bahwa masing-masing guru yang mengikuti pembinaan melalui pengenalan ICT sebagai salah satu media pembelajaran memiliki peningkatan kemampuan pada siklus 3 dan tidak perlu perbaikan. Lebih jelasnya disajikan pada Gambar 3.

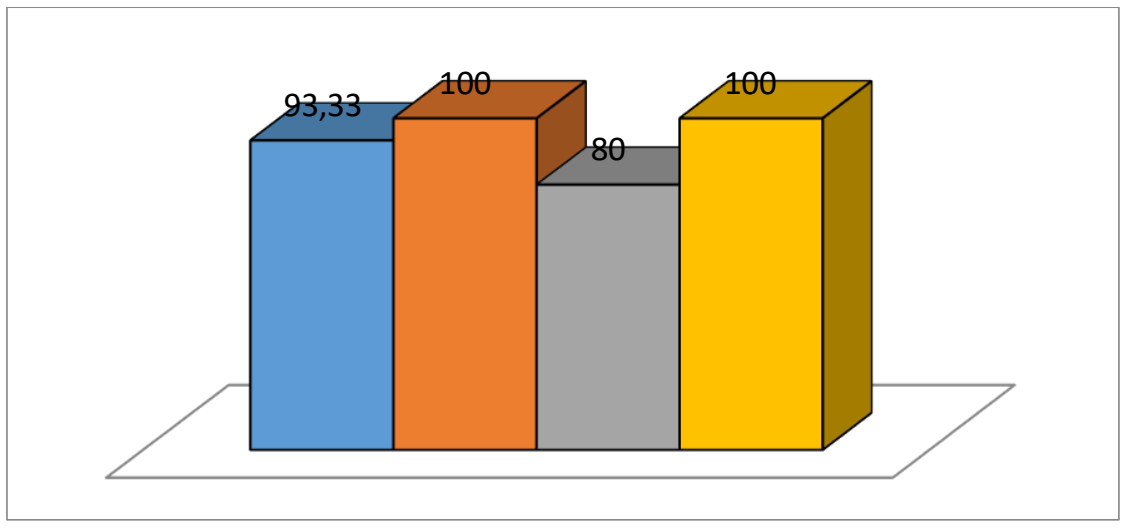

Gambar 3. Kemampuan Guru dalam Penguasaan ICT Siklus 3

Keterangan:

Biru : Pemahaman terhadap ICT

Merah : Kompetensi Kooperatif Guru menggunakan ICT

Hijau : Aplikasi

Ungu : Kompetensi Partisipatif dalam Kegiatan Pembelajaran

Bertolak dari seluruh rangkaian kegiatan, maka dapat dikatakan bahwa perkembangan teknologi informasi dan komunikasi yang semakin pesat telah merambah berbagai aspek kehidupan manusia, termasuk menyentuh dunia pendidikan. Karena itu, sekolah dan guru tidak dapat mengelak dari trend ini hanya karena persoalan anggaran atau pun persoalan keterbatasan akses dan wawasan.Satu hal yang harus dilakukan adalah melangkah maju dan menceburkan diri tanpa ragu ke dalam arus teknologi ini untuk kemajuan dunia pendidikan kita.

Guru sejatinya memberi contoh kepada siswa bahwa teknologi merupakan suatu keniscayaan yang sedang dihadapi, sehingga penguasaan teknologi adalah sesuatu yang harus direbut oleh siswa (Supriadi, 1994). Pemanfaatan teknologi infomasi dan komunikasi dalam kegiatan pembelajaran perlu diusahakan oleh guru sesuai dengan kemampuan masing-masing sekolah dan guru bersangkutan. Bahwa terdapat tantangan-tantangan seperti keterbatasan anggaran untuk melengkapi infrastruktur yang mendukung pada penguasaan teknologi informasi dan komunikasi ini adalah fakta, namun satu hal yang perlu dilakukan adalah membuat satu langkah awal yang mengarah pada penguasaan teknologi baik oleh guru maupun oleh siswa.Satu langkah awal selalu diikuti oleh langkah berikutnya dan terkadang oleh suatu lompatan besar.Karena itu, sekolah dan guru harus memprioritaskan penguasaan dan pemanfaatan teknologi informasi dan komunikasi dalam program prioritas. 


\section{KESIMPULAN}

Berdasarkan hasil penelitian dan pembahasannya dapat disimpulkan bahwa :

1. Kompetensi pedagogik dapat ditingkatkan memalui penggunaan media ICT. Hal tersebut dibuktikan dengan pelaksanaan penelitian tindakan yang dilakukan selama 3 siklus, dimana pada ke 3 siklus tersebut kemampuan guru dalam penguasaan media pembelajaran dan kegiatan pembelajaran terus meningkat.

2. Aspek pemahaman terhadap ICT, sikap kooperatif guru selama kegiatan, aplikasi dan partisipasi aktif dalam kegiatan pembelajaran pada kompetensi pedagogik guru menunjukkan hasil peningkatan.

Adapun saran yang akan disampaikan berdasarkan pada uraian pada penelitian tindakan sekolah ini adalah:

1. Perlu diadakan pelatihan ICT lebih lanjut seperti penggunaan internet dan aplikasi lainnyamisalnya saja microsoft Office khususnya powerpoint, aplikasi membuat animasi, Blog, website, email, internet untuk para guru di setiap sekolah agar para guru mampu melaksanakan kegiatan pembelajaran berbasis ICT.

2. Alokasi anggaran untuk pelatihan dan penyediaan infrastruktur ICT dalam RAPBS perlu mendapatkan porsi yang besar untuk mendukung akselerasi penguasaan teknologi oleh guru dan siswa.

3. Perlu adanya komunikasi yang intensif dan produktif terutama antara pihak sekolah dengan masyarakat khususnya komite sekolah dalam menentukan prioritas anggaran sekolah dan menentukan besaran anggaran yang dapat diperoleh dari masyarakat.

4. Perlu adanya kesamaan persepsi diantara guru tentang pentingnya teknologi informasi dan komunikasi dengan memprioritaskan kepemilikan personal computer (PC) di rumah masingmasing dengan spesifikasi yang memadai untuk mengakses internet.

5. Perlu adanya dialog dengan masyarakat sebagai stockholder pendidikan tentang programprogram sekolah untuk mendapatkan support dan dukungan dari masyarakat dan untuk menumbuhkan rasa tanggung jawab terhadap keberhasilan program sekolah. Akhirnya, berhasil tidaknya kita meningkatkan penggunaan TIK/ICT ini tergantung pada kemauan kita yaitu: pimpinan, guru, siswa,TU dan seluruh komponen yang ada di sekolah. Pemerintah sudah memfasilitasi, tinggal kita memanfaatkan dengan sepenuh hati.

\section{REKOMENDASI}

Penelitian ini dilaksanakan dengan tiga siklus dikarenakan hasil dari refleksi siklus 1 dan 2 belum maksimal sehingga dilakukan siklus ke-3. Siklus yang dilakukan pada penelitian tidak harus selalu tiga siklus bias saja hanya 2 atau bahkan 1 siklus saja tergantung hasilnya.

\section{UCAPAN TERIMAKASIH}

Ucapan terima kasih ditujukan kepada kepala SD Negeri Karsamenak Kota Tasikmalaya karena telah mengizinkan penelitian ini dilaksanakan. Selain itu juga terimakasih kepada subjek dalam penelitian ini yakni guru SD Negeri Karsamenak Kota Tasikmalaya dengan jumlah sebanyak 9 orang yang telah mendukung pelaksanaan penelitian ini.

\section{DAFTAR PUSTAKA}

Lunandi. (1993). Pendidikan Orang Dewasa: Sebuah Uraian Praktis untuk Pembimbing, Penatar, Pelatih dan Penyuluh Lapangan. Jakarta: Gramedia

Marno \& Idris. (2008). Strategi dan Metode Pengajaran Menciptakan Keterampilan Mengajar yang Efektif dan Edukatif. Yogyakarta: Ar-Ruzz Media Group. 
Sanjaya, W. (2007). Strategi Pembelajaran Berorientasi Standar Proses Pendidikan. Jakarta: Penerbit Kencana Prenada Media.

Siahaan, S. (2001). E-Learning (Pembelajaran Elektronik) sebagai Salah Satu Alternatif Kegiatan Pembelajaran. (sumber: http://www.depdiknas.go.id/Jurnal/ 42/sudirman.htm)

Supriadi, S. (1994). Kreativitas, Kebudayaan \& Perkembangan IPTEK. Bandung: Alfabeta. 